FACTA UNIVERSITATIS

Series: Physical Education and Sport, Vol. 17, No 3, 2019, pp. 619 - 633

https://doi.org/10.22190/FUPES191211056Z

Research article

\title{
KNOWLEDGE AND USE OF NUTRITIONAL SUPPLEMENTS IN DIFFERENT DANCE DISCIPLINES
}

\author{
UDC 613.2:797.3
}

\section{Petra Zaletel}

Faculty of Sport, University of Ljubljana, Ljubljana, Slovenia

\begin{abstract}
In aesthetic sports the appearance of the body figure and its leanness plays an important role, therefore energy intake is often barely sufficient. By limiting the amount of food consumed, there are specific deficits that affect the health and performance of the dancer. The use of dietary supplements often compensates for the lack of nutrient intake and enables faster regeneration. Our study aimed to analyse the knowledge about nutrition and nutritional supplements in male and female dancers of four different dance disciplines: hip hop, Latin American and standard dances, acrobatic rock and roll, and breakdance. The sample consisted of 98 dancers (av. 18.8 years), who were compared by gender and by their involvement in the dance discipline. Their average length of dance career is 9.7 years. We found that dancers have an average knowledge about nutrition and nutritional supplements (5.1/10). Dancers put the most trust in physicians and trainers when it comes to nutrition knowledge. Dancers gather information about nutrition supplements mostly from the coaches or from teachers at school, and some dancers also independently, through the internet and literature. Less than half of the female dancers do not use nutritional supplements. Most of them consume energy bars and vitamin-mineral supplements. Male dancers regularly consume vitamin-mineral supplements (26.7\%), occasionally more energy-efficient bars (42\%) and isotonics (26.6\%). Representatives of different dance disciplines do not differ significantly in the knowledge and use of nutritional supplements. Rock and roll dancers have the highest average rating in nutritional knowledge (5.3/10).
\end{abstract}

Key words: Nutrition, Supplements, Dance, Knowledge

\section{INTRODUCTION}

Dance is a sport discipline that requires a high level of dedication and skill; therefore dancers are increasingly recognized as elite athletes (Uzunović \& Kostić, 2005). For optimal performance at the professional level, dancers must be experts in the aesthetic and technical

Received December 11, 2019/ Accepted December 23, 2019

Corresponding author: Petra Zaletel

Faculty of Sport, University of Ljubljana, Gortanova 22, 1000 Ljubljana, Slovenia

Phone: + 386152077 00• E-mail: petra.zaletel@fsp.uni-lj.si 
components of the art, psychologically prepared to handle the critical and stressful situations, and remaining at the same time free from injury (Koutedakis \& Jamurtas, 2004). Dancers must be physically 'fit', and must be able to successfully maintain energy supplies (Koutedakis, 1996). Prolonged deficits in any of the nutrients could cause health and provoke dance performance impairment. Dancers' complex movements include demanding technical often acrobatic and gymnastic - elements, whose prerequisite is a movement in motion extremes, cardiovascular and respiratory abilities (Koutedakis, 1996). Dance is a highintensity intermittent exercise, where a good aerobic foundation is vital for its execution (Allen \& Wyon, 2008). Compared to other athletes, dancers, despite their extreme physical demands (Challis, Stevens, \& Wilson, 2016; Elpidoforou, 2016) are well prepared to perform specific activities in their dance discipline, but in poor basic physical fitness, e.g. general strength and endurance (Allen \& Wyon, 2008). The latter could be the underlying source of many injury problems. Laws (2005) noted that the majority of dancers perceived that the tiredness and fatigue were the triggers of their injuries. As dance is a high skill movement form and even mild fatigue has a major effect on the quality of performance, resulting in poor alignment of lower extremities, and therefore misplacement of acting force (Allen \& Wyon, 2008).

One of the main reasons for fatigue occurrence is quite often inadequate energy intake (Bronner, Ojofeitimi, \& Woo, 2015). Not only sufficient energy intake but also a suitable nutrient selection is required to achieve optimal fitness in dance. While ballet dancers often have problems with inadequate energy intake (Civil et al., 2018), there is a problem of poor nutrition selection among modern dance styles (fast food, cold diet), whose outcome is the insufficient consumption of micronutrients. Nutritional supplements can help meet energy requirements when nutritional intake is too low, but, nevertheless, due to poor nutritional knowledge of dancers (Hunt, 2011; Pacy, Khalouha, \& Koutedakis, 1996), professional nutritional counselling is advised.

Nutrition research has shown inadequate dietary intake in some groups of athletes, according to their daily activities. Inadequate nutritional intake is particularly prominent in sports disciplines, where a higher proportion of lean body mass and a lower body weight are desirable - body mass index (e.g. gymnastics, dance, synchro-swimming, athletics, cycling, ski jumping) (Hidayah \& Syahrul Bariah, 2011; Hunt, 2011; Dotti et al., 2002; Pacy et al., 1996). In aesthetic sports, where the appearance of the body (leanness) also plays an important role, energy intake and thus nutrients are often barely satisfactory. Athletes of different disciplines and age categories, including the gender of the athlete, have specific dietary requirements that must compensate for the loss of energy supplies during the training process (Desbrow, Burd, Tarnopolsky, Moore, \& Elliott-Sale, 2019). By limiting the amount of food consumed, specific deficits can occur, e.g., lack of calcium, iron, some B-group vitamins, zinc, etc. (Biček, 2009). Quantitatively or qualitatively inadequate nutrition affects health, and also increases the occurrence of injury, which can be caused by fatigue, overload of the joints and tissues, and worse regeneration, due to insufficient energy input (Challis et al., 2016).

Fatigue and exhaustion often drive dancers to the use of supplements that compensate the lack of nutrient intake and allow the fastest possible regeneration. Sports nutrition is an area that is currently receiving a lot of attention in top sports, both in terms of nutritional supplements and anti-doping.

An international survey on the use of nutritional supplements in 334 dancers from 53 countries (Brown \& Wyon, 2014) found that $48 \%$ of dancers regularly consume dietary supplements, mainly to maintain good health, to increase immunity and to reduce fatigue. 
$45 \%$ believe that the dance training process encourages the use of supplements, while $30 \%$ believe that consuming supplements is risky. The most commonly consumed are vitamin $\mathrm{C}$ $(60 \%)$, multivitamins $(67 \%)$ and caffeine (72\%). A smaller percentage of respondents consumed protein supplements $(21 \%)$ or creatine $(14 \%)$. In the study, the dancers acknowledged that they had a lack of knowledge about consuming nutritional supplements and relied on peer recommendations rather than reliable evidence based on the advice of recognized nutrition or health professionals. This study proved that the use of nutritional supplements is widespread among dancers. We are wondering if the situation is similar in Slovenia.

Sousa, Carvalho, Moreira, \& Teixeira (2013) propose an intake of at least 30kcal per $\mathrm{kg}$ of lean body mass per day to reduce energy balance risk in dancers, considering the additional energy consumption in training. They point out that supplements suitable for dancers are multivitamins, iron, calcium and vitamin D, sports drinks, energy tablets and also caffeine as an ergogenic substance.

When examining the use and knowledge of nutritional supplements in hip hop dance (Pruš, Kondrič, Hadzić, \& Zaletel, 2019), we found that $42.1 \%$ of the surveyed dancers supplement, of which only $10.5 \%$ regularly. The use of supplements and a better knowledge of nutrition is prevalent among more successful dancers. There is still a high percentage of those who do not consume supplements, probably due to ignorance and/or lack of information (48\%). Better body composition of more successful dancers does not affect the knowledge and/or use of nutritional supplements.

In order to successfully participate in dance training, rehearsals, performances or competitions, dancers must meet the appropriate nutritional requirements. Due to the tendency for a lean and elegant body figure that allows light and aesthetically pleasing movements, many female dancers suffer from eating disorders, as evidenced by many studies in Slovenia and abroad (Hidayah \& Syahrul Bariah, 2011; Zaletel et al., 2017). Dance training, by itself, does not always provide proper conditioning for the dancers (Malkogeorgos, Zaggelidou, Zaggelidis, \& Christos, 2013). Therefore, dancers are open to different forms of diets in order to achieve and maintain a lean and aesthetically pleasing appearance, which often leads to eating disorders (Sekulić, Perić, \& Rodek, 2010). Particularly problematic is the population of ballet dancers, of whom at least $50 \%$ have experienced anorexia or bulimia at least once in their careers (Hunt, 2011).

The aim of the study was to analyse the knowledge about nutrition and nutritional supplements in male and female dancers of four different dance disciplines: hip-hop, standard and Latin-American dances, acrobatic rock and roll and breakdance. We were interested in how often and what kind of nutritional supplements dancers consume, whom they put their trust into when it comes to supplements, and where they gain information about nutrition and supplements. We believe that this is essential in preventing the misuse of substances and important for the proper and systematic use of permissible substances.

\section{METHODS}

\section{Participants}

The survey included 98 of the most successful dancers in Slovenia from seven leading Slovene clubs, where female dancers represented $55.1 \%$ of all the respondents $(\mathrm{N}=54$, average height $164.4 \mathrm{~cm}$ and average mass $58.3 \mathrm{~kg}$ ), while the proportion of male 
dancers represented $44.9 \%(\mathrm{~N}=44$, average height $177.6 \mathrm{~cm}$ and average weight $73.8 \mathrm{~kg})$. The sample included 19 Latin-American and standard (STLA) dancers, 20 acrobatic rock and roll (RR) dancers, 37 hip hop $(\mathrm{HH})$ dancers, and 22 Break-dance (BD) representatives. All of the respondents were between 16 and 29 years old, with an average age of 18.8, were high school or faculty students, and they had been dancing for an average of 9.7 years. The respondents in the survey dance under the auspices of the Slovenia Dance Federation (PZS) and the International Dance Associations (WRRC, WDSF, IDO) and all achieve top results; they are finalists of national championships and international competitions.

\section{Instruments}

To determine the knowledge and use of nutritional supplements, we used an anonymous questionnaire, which, in addition to the basic demographic data (gender, age, education), included data on the duration of a dance career in the selected dance discipline, training volume, followed by questions on the use of nutritional supplements and knowledge about nutrition. The author of the questionnaire is Damir Sekulić, PhD. The questionnaire is validated, standardized and repeatedly used in various surveys (Šeme, 2016; Zaletel et al., 2015; Sekulić, Bjelanović, Pehar, Pelivan, \& Zenić, 2014a; Sekulić, Milanović, Bok, Jukić, \& Matika, 2014b; Kondrič, Sekulić, Uljević, Gabrilo, \& Žvan, 2013; Šajber, Rodek, Escalante, Olujić, \& Sekulić, 2013).

\section{Procedures}

The dancers were tested in the physiology laboratory of the Faculty of Sport in Ljubljana, where, before measuring the morphological and motor dimensions, they first filled out the questionnaire individually and submitted it in closed envelopes, each with its own anonymous code. Before the measurements, they signed a declaration of voluntary participation and allowed the use of the results for research purposes.

Data was processed with the statistical program IBM SPSS 26 (SPSS Inc., Chicago, USA), and graphical representations were prepared with Microsoft Excel (Microsoft, Redmond, USA). Basic statistical parameters were calculated for all variables.

The normality of the distribution was verified by the Shapiro-Wilk test and the homogeneity of the variance by the Leven test. A t-test for independent samples and its non-parametric form (Mann-Whitney's U test) was used to determine gender differences, and a one-way analysis of variance and its non-parametric form (Kruskal-Wallis test) were used to determine differences between different dance disciplines. The differences between the different groups of variables were checked by the PostHoc test. Statistical significance was confirmed at the level of $5 \%$ probability of error $(\mathrm{p} \leq .05)$.

\section{RESULTS}

The descriptive statistical characteristics of the sample showed that the dancers have been training in their discipline for an average of 9.7 years. To determine the differences between male and female dancers of all four selected dance disciplines, we used the t-test for independent samples and its non-parametric form (Mann-Whitney test). We found that there is no difference between male and female dancers in knowledge about nutrition 
and nutritional supplements. The male dancers are statistically significantly older than the females, although they have been training dance about the same length of time.

Table 1 Comparison between male and female dancers of the whole sample

\begin{tabular}{lrrrrrrrr}
\hline & \multicolumn{2}{c}{$\begin{array}{c}\text { Males } \\
(\mathrm{N}=45)\end{array}$} & \multicolumn{2}{c}{$\begin{array}{c}\text { Females } \\
(\mathrm{N}=53)\end{array}$} & t-test & \multicolumn{2}{c}{$\begin{array}{c}\text { Mann- } \\
\text { Whitney test }\end{array}$} \\
\cline { 2 - 10 } & $\mathrm{M}$ & $\mathrm{SD}$ & $\mathrm{M}$ & $\mathrm{SD}$ & $\mathrm{t}$ & $\mathrm{p}$ & $\mathrm{z}$ & $\mathrm{p}$ \\
\hline Age & 19.61 & 3.46 & 18.17 & 2.85 & - & --2.782 & $\mathbf{. 0 1}$ \\
Years of training & 9.67 & 4.36 & 9.64 & 4.15 & .029 & .98 & - & - \\
Knowledge about nutritional supplements & 4.93 & 2.47 & 5.26 & 1.91 & -.746 & .46 & - & - \\
\hline
\end{tabular}

Legend: M- Mean; SD- Standard Deviation; z- Test Difference;

p- Statistical Significance, ${ }^{* *}$ - Statistical Significance $(\mathrm{p} \leq .01)$

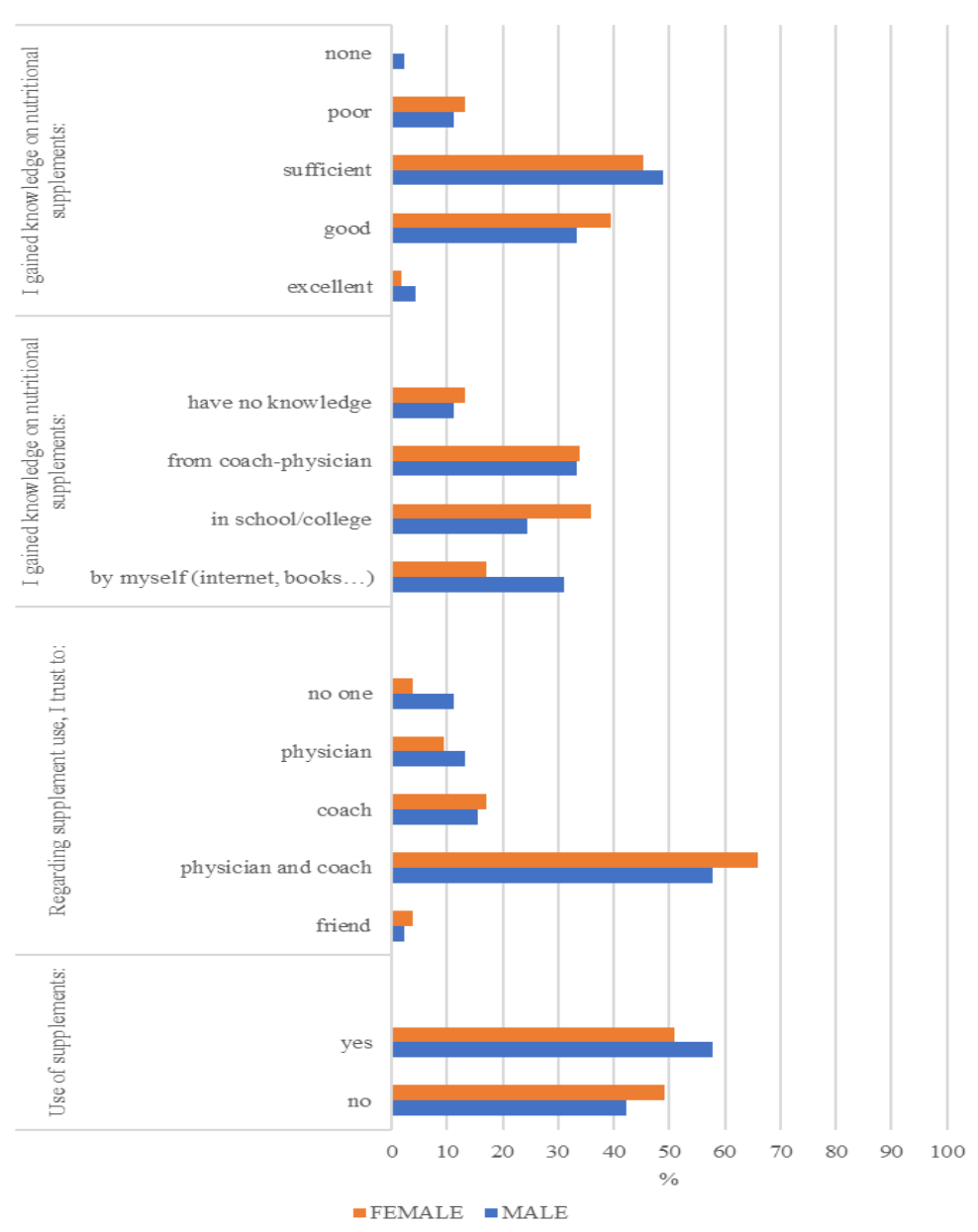

Fig. 1 Comparisons between all male and female dancers in assessing their nutrition knowledge, where they get their information from, whom they believe regarding nutrition and nutritional supplements, and if they use nutritional supplements 
Male and female dancers have a very similar opinion about their nutrition knowledge. Less than half evaluated their knowledge as sufficient, while a third rated their knowledge of nutrition and nutritional supplements as good. Females (36\%) gained much more knowledge of nutrition and nutritional supplements than males (24\%) in school. In terms of nutrition and nutritional supplements, male dancers still trust the coach and physician the most (33\%), and to a great extent also female dancers (34\%), but many more males $(31 \%)$, compared to females $(17 \%)$, gain their knowledge independently, through the internet or literature. As many as $11 \%$ of males and $13 \%$ of females said that they had no knowledge of nutrition and nutritional supplements. The evaluated knowledge of nutrition and nutritional supplements showed that out of a possible 10 points, the males achieved a nutritional supplement knowledge rating of 4.9 and females of 5.3.

Almost half of the female dancers do not use nutritional supplements at all, $37.7 \%$ use supplements occasionally and $13.2 \%$ regularly. Most females occasionally use energy tablets and vitamin-mineral supplements. About $20 \%$ of the females occasionally consume isotonic drinks and proteins. They rarely consume a combination of regeneration drinks and iron.

Many more male dancers, compared to females, use supplements regularly, every day (24.4\%), while occasionally just over a third. Most male dancers occasionally consume energy bars (42.2\%), isotonics (26.6), and $26.7 \%$ of male dancers consume vitamin-mineral supplements regularly. Only $11 \%$ of dancers regularly consume protein and carbohydrate supplements. Females occasionally mostly consume energy chocolates (40\%) and vitaminmineral supplements $(35.8 \%)$, while regularly mentioned supplements are consumed by only $15 \%$. As many as $79 \%$ of female dancers never consume carbohydrate supplements, $66 \%$ never consume iron, $62.3 \%$ never consume isotonics and regeneration drinks, and $60 \%$ never consume protein.

Table 2 Use of nutritional supplements for male and female dancers of different dance disciplines

\begin{tabular}{|c|c|c|c|c|c|c|c|c|c|}
\hline & Gender & & $\begin{array}{l}\text { Vitamin- } \\
\text { Mineral }\end{array}$ & $\begin{array}{c}\text { Carbo- } \\
\text { Hydrates }\end{array}$ & Proteins & Isotonics & Iron & $\begin{array}{l}\text { Combination } \\
\text { of Drinks for } \\
\text { Regeneration }\end{array}$ & $\begin{array}{c}\text { Energy } \\
\text { Chocolates }\end{array}$ \\
\hline \multirow{4}{*}{$\begin{array}{l}\vec{J} \\
\text { ते } \\
\text { d }\end{array}$} & \multirow{2}{*}{ male } & $\mathrm{N}$ & 12 & 5 & 5 & 2 & 3 & 3 & 3 \\
\hline & & $\%$ & 26.7 & 11.1 & 11.1 & 4.4 & 6.7 & 6.7 & 6.7 \\
\hline & \multirow{2}{*}{ female } & $\mathrm{N}$ & 8 & 2 & 4 & 1 & 2 & 0 & 0 \\
\hline & & $\%$ & 15.1 & 3.8 & 7.5 & 1.9 & 3.8 & 0 & 0 \\
\hline \multirow{4}{*}{ 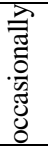 } & \multirow{2}{*}{ male } & $\mathrm{N}$ & 8 & 3 & 10 & 12 & 2 & 5 & 19 \\
\hline & & $\%$ & 17.8 & 6.7 & 22.2 & 26.7 & 4.4 & 11.1 & 42.2 \\
\hline & \multirow{2}{*}{ female } & $\mathrm{N}$ & 19 & 4 & 11 & 12 & 8 & 11 & 21 \\
\hline & & $\%$ & 35.8 & 7.5 & 20.8 & 22.6 & 15.1 & 20.8 & 39.6 \\
\hline \multirow{4}{*}{ 离 } & \multirow{2}{*}{ male } & $\mathrm{N}$ & 10 & 7 & 6 & 8 & 11 & 6 & 7 \\
\hline & & $\%$ & 22.2 & 15.6 & 13.3 & 17.8 & 24.4 & 13.3 & 15.6 \\
\hline & \multirow{2}{*}{ female } & $\mathrm{N}$ & 2 & 5 & 6 & 7 & 8 & 9 & 9 \\
\hline & & $\%$ & 3.8 & 9.4 & 11.3 & 13.2 & 15.1 & 17 & 17 \\
\hline \multirow{6}{*}{ 㐫 } & \multirow{2}{*}{ male } & $\mathrm{N}$ & 15 & 30 & 24 & 23 & 29 & 31 & 16 \\
\hline & & $\%$ & 33.3 & 66.7 & 53.3 & 51.1 & 64.4 & 68.9 & 35.6 \\
\hline & \multirow{4}{*}{ female } & $\mathrm{N}$ & 24 & 42 & 32 & 33 & 35 & 33 & 23 \\
\hline & & $\%$ & 45.3 & 79.2 & 60.4 & 62.3 & 66.0 & 62.3 & 43.4 \\
\hline & & $\mathrm{Z}$ & -1.315 & -1.324 & -.609 & -.930 & -.325 & -.856 & -.253 \\
\hline & & $\mathrm{p}$ & .19 & .19 & .54 & .35 & .75 & .39 & .80 \\
\hline
\end{tabular}


We compared dancers of different dance disciplines and found a statistically significant difference only in the variable who is to be believed and trusted on the topic of nutrition supplements (sig=.01). In terms of nutrition and nutritional supplements, hip hop (73\%) and rock and roll representatives $(70 \%)$ have the greatest confidence in the physician and coach together (Fig. 2). Only 50\% of break-dancers and $47 \%$ of Latin-American and standard dancers trust the coach and physician together. Only $15 \%$ of Latin-American and standard dancers trust their coach, who is most trusted by rock and roll dancers $(18 \%)$.

Table 3 Comparisons between groups of different dance disciplines

\begin{tabular}{|c|c|c|c|c|c|c|c|c|c|c|c|c|c|c|}
\hline & \multicolumn{2}{|c|}{$\begin{array}{c}\mathrm{HH} \\
(\mathrm{N}=37)\end{array}$} & \multicolumn{2}{|c|}{$\begin{array}{c}\text { LAST } \\
(\mathrm{N}=19)\end{array}$} & \multicolumn{2}{|c|}{$\begin{array}{c}\mathrm{RR} \\
(\mathrm{N}=20)\end{array}$} & \multicolumn{2}{|c|}{$\begin{array}{c}\mathrm{BD} \\
(\mathrm{N}=22)\end{array}$} & \multicolumn{2}{|c|}{$\begin{array}{c}\text { ALL } \\
(\mathrm{N}=98)\end{array}$} & \multicolumn{2}{|c|}{$\begin{array}{l}\text { One-way } \\
\text { ANOVA }\end{array}$} & \multicolumn{2}{|c|}{$\begin{array}{l}\text { Kruskal- } \\
\text { Wallis test }\end{array}$} \\
\hline & M & $\mathrm{SD}$ & M & SD & M & SD & M & SD & M & SD & $\mathrm{F}$ & $\mathrm{p}$ & $\mathrm{H}$ & $\mathrm{p}$ \\
\hline Age & 18.8 & 3.4 & 17.8 & 1.5 & 18.8 & 3.2 & 19.8 & 3.8 & 18.8 & 3.2 & - & - & 2.882 & .41 \\
\hline Years of training & 10.1 & 4.6 & 8.89 & 4.0 & 9.35 & 4.6 & 9.86 & 3.6 & 9.7 & 4.2 & .376 & .76 & - & - \\
\hline $\begin{array}{l}\text { Knowledge about } \\
\text { nutrition \& nutritional } \\
\text { supplements }\end{array}$ & 5.08 & 1.7 & 5.00 & 2.7 & 5.3 & 2.7 & 5.09 & 2.0 & 5.1 & 2.2 & .067 & .89 & - & - \\
\hline
\end{tabular}

Legend: M- Mean; SD- Standard Deviation; F, H- Test Statistics; p- Statistical Significance

Although dancers of different dance disciplines do not differ in their knowledge of nutrition and nutritional supplements, on average, the representatives of acrobatic rock and roll have the highest knowledge of all (5.3/10).

The highest number of Latin-American and standard dancers $(26.3 \%)$ regularly consume nutritional supplements, followed by about $20 \%$ of hip hop and rock and roll dancers (all consume vitamin and mineral supplements the most) and only $4.5 \%$ of break-dancers. They consume the most supplements occasionally - 31.8\% (mainly proteins). Many more dancers enjoy nutritional supplements occasionally: $42.2 \%$ of hip hop representatives, $36.8 \%$ LatinAmerican and standard dancers and $25 \%$ rock and roll dancers. Nutrition supplements are never enjoyed by $63.6 \%$ of break-dancers, $55 \%$ of rock and roll dancers, $37 \%$ of LatinAmerican and standard dancers, and $35.1 \%$ of hip hop dancers.

Hip Hop and Latin-American and standard dancers gained most of their knowledge on nutrition and nutritional supplements through school and college (approx. 40\%) and through trainers and physicians (approx. 33\%), while rock and roll dancers have obtained most of their nutrition information through a coach $(50 \%)$.

$10 \%$ of rock and roll dancers rated their knowledge of nutrition and nutritional supplements as excellent. However, most rock and roll representatives are more critical of their nutrition knowledge, with some assessing their skills as poor (RR 20\% and BD 13\%), and most believe their nutrition knowledge is sufficient (RR 40\% and BD 45\%). Representatives of hip hop evaluated they have a sufficient $(51 \%)$ and good $(38 \%)$ knowledge of nutrition, similar to those of Latin-American and standard dances (sufficient $47 \%$ and good $42 \%$ ). 


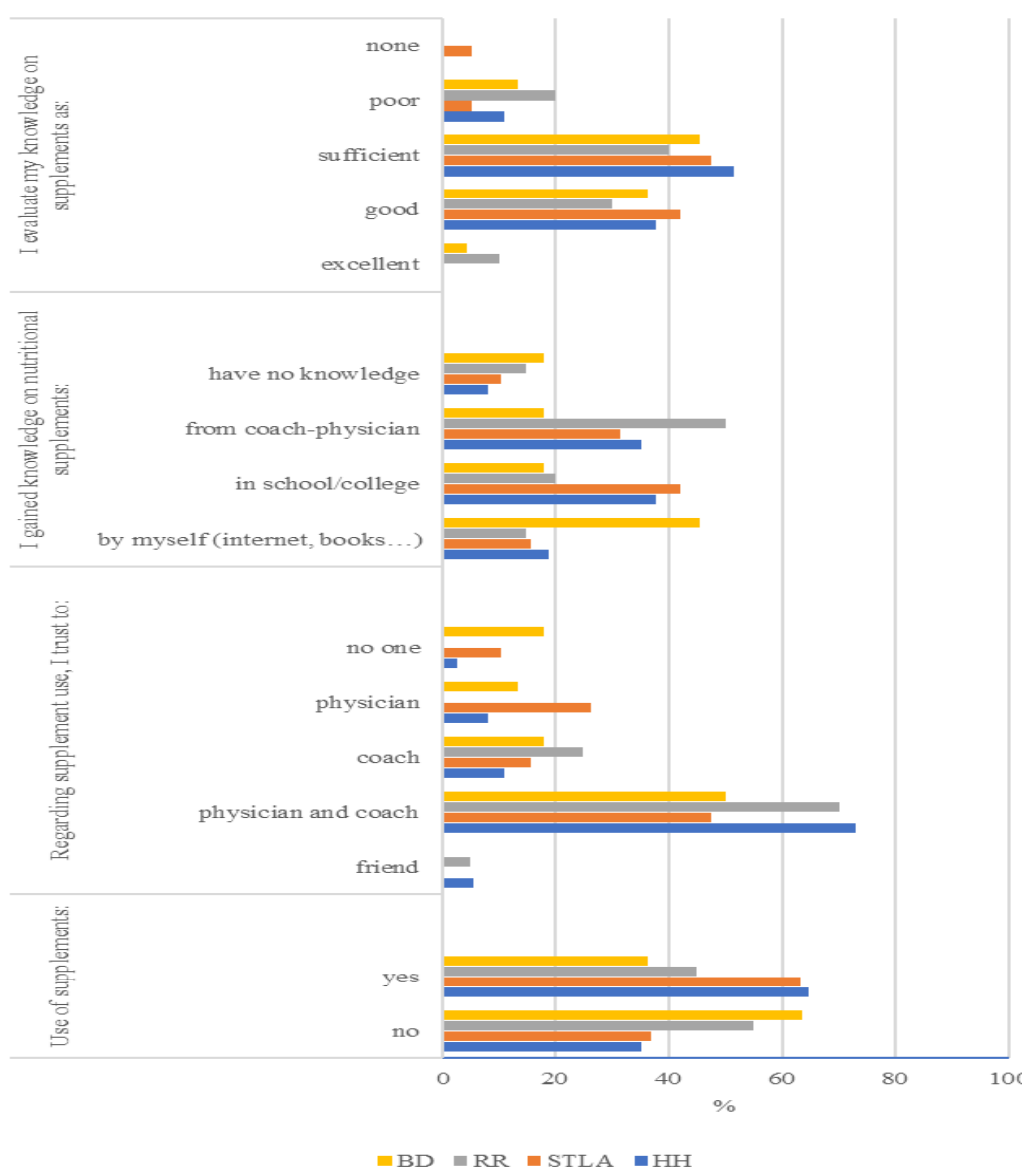

Fig. 2 Comparisons between representatives of different dance disciplines (BD- breakdance, RR- acrobatic rock and roll, STLA- Latin-American and standard dances, HH- hip hop) in assessing their nutrition knowledge, where they get information from, who they believe regarding nutrition and nutrition supplements and if they use nutritional supplements

More than $30 \%$ of Latin-American and standard dancers consume vitamin-mineral supplements every day, $15 \%$ of them consume proteins, iron and isotonics every day. Hip Hop dancers consume vitamin-mineral supplements $(16 \%)$ and protein $(11 \%)$ every day, rock and roll dancers consume vitamin-mineral supplements $(30 \%)$, protein $(10 \%)$ and energy chocolates $(10 \%)$ every day. Dancers usually use supplements occasionally, not every day. The most common supplements consumed occasionally are energy tablets (mainly hip hop dancers 54\%, Latin-American standard $47 \%$ and rock and roll $40 \%$ ), while occasional protein use is the most common in breakdancing (27.3\%). About $80 \%$ of break-dancers never consume most of the supplements (isotonics, iron, carbohydrates and regeneration drinks. 
Table 4 Use of nutritional supplements in representatives of different dance disciplines

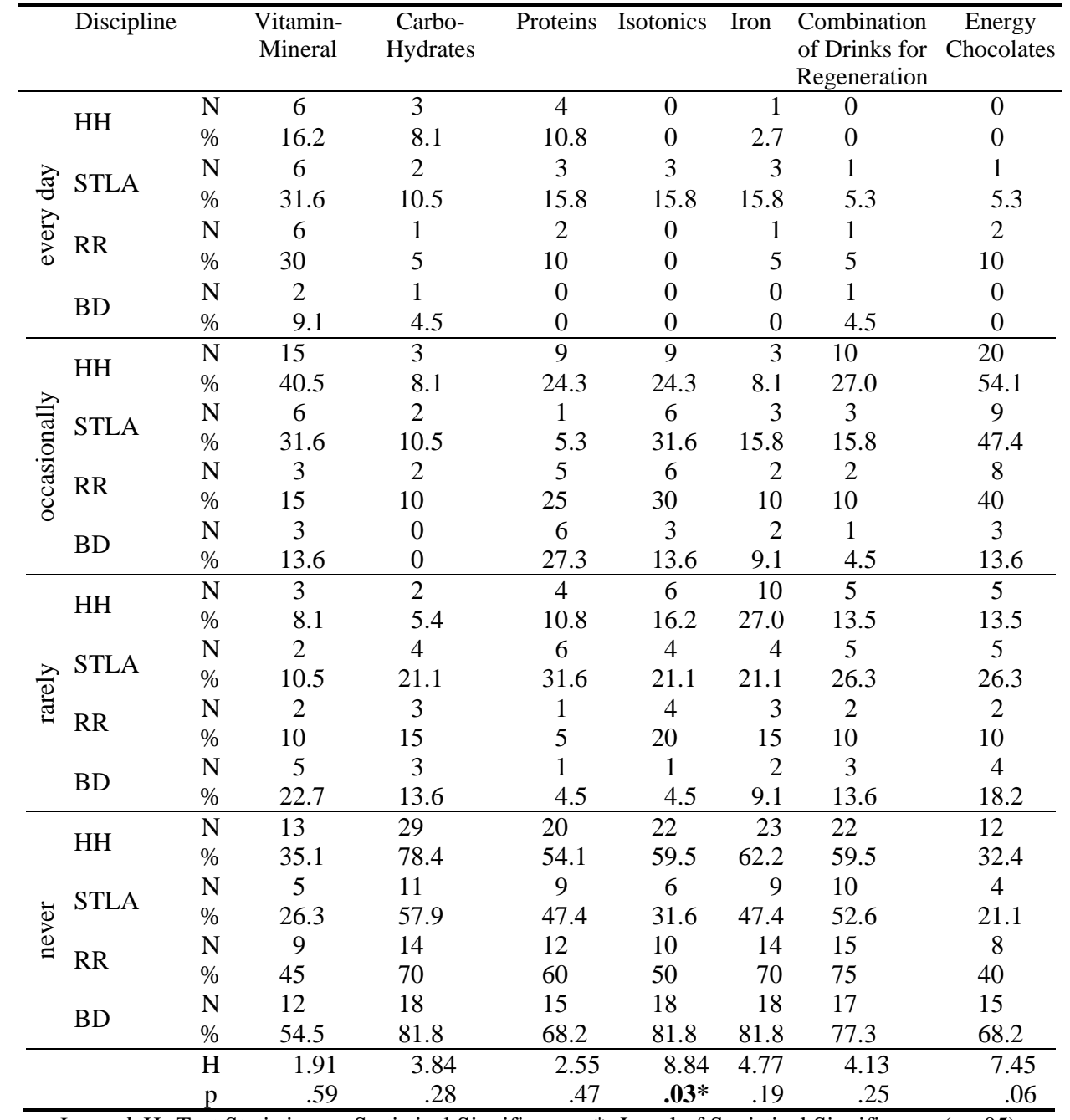

Legend: H- Test Statistics; $\mathrm{p}$ - Statistical Significance; *- Level of Statistical Significance ( $\mathrm{p}<.05)$; (HH- hip hop, STLA- Latin-American and standard, RR- rock and roll, BD- break-dance)

\section{DISCUSSION}

Rock and roll female dancers are the shortest and the lightest because they need to control their body in order to perform acrobatics successfully. Latin-American and standard females also have a low body mass index, since the requirements for lean dancers on stage are important for meeting the aesthetic criteria of this dance discipline. Latin-American female dancers appear to be lighter and shorter than standard dancers (Bria et al., 2011). Mastering the movement and leaner body on the dance floor gives the impression of a fluid, feminine yet technically perfect movement of the dancer, attractive to the eyes of the judge and the 
audience, also more authentic in the expressiveness of the individual dance (Kostić, Zagorc, \& Uzunović, 2004). Hip hop females are a little heavier on average, since explosive power of the legs is more important in their movement (Pruš, 2015). Hip hop dancers are supposed to give an impression of a powerful dancer, their clothes are much looser than the LatinAmerican dancers' tight dresses, high heels or acrobatic rock and roll females, who are dressed in jerseys and nylons.

Dancers' knowledge of nutrition is comparable to many other athletes, as similar values have been achieved in other sports (synchronous swimming, swimming, table tennis) (Furjan-Mandić, Perić, Krželj, Stanković, \& Zenić, 2013; Kondrič et al., 2013). Pruš (2018) noted that more successful dancers have higher knowledge of nutrition and nutritional supplements. She established that the knowledge of hip hop dancers ranged between 2.5 and 3.3, which was comparable to the results of the knowledge of Slovenian and Croatian badminton players (Šeme, 2016). Professional low-weight ballet dancers with an eating disorder have a lower level of nutrition knowledge (Wyon, Hutchings, Wells, \& Nevill, 2014), meaning that dancers' nutrition education would also often address the problems of eating disorders and energy deficit of dancers.

Dancers entrust the content and importance of nutritional supplements mostly to their physician and coach. Kondrič et al. (2013) found that female tennis players highly trust their coaches in substance use and sports nutrition. Trust in a coach in this area is important in preventing accidental doping. In this case, the athlete does not rely on her knowledge of permissive and prohibited substances. Thus, the knowledge of coaches in this field is essential in preventing the use of doping. A study of 236 student athletes also found that the primary sources of nutritional information are sports coaches (40\%), fitness coaches $(24 \%)$ and dietitians $(14 \%)$, and that as many as $88 \%$ of all student athletes use dietary supplements (Burns, Schiller, Merrick, \& Wolf, 2004).

Most female dancers occasionally use energy tablets and vitamin-mineral supplements. Similarly, so do male dancers, though many more use supplements on a regular basis, every day. Only about $20 \%$ of female dancers occasionally consume isotonic drinks and proteins. They rarely consume a combination of regeneration and iron beverages. In the survey of professional ballet female dancers (Sekulić et al., 2010), isotonics are used to a much greater extent $(63 \%)$.

Research by Perić, Zenić, Sekulić, Kondrič, \& Zaletel (2016) showed that, due to high volume and strenuous training, professional ballet dancers achieved a relatively high prevalence of nutritional supplementation (almost 2/3), which is in line with some other studies (Zenić, Perić, Zubcević, Ostojić, \& Ostojić, 2010). It is likely that the need for supplements is greater in professional dance and full-day training and rehearsal than among amateur dancers in our study.

Considering that only $15 \%$ of Latin-American and standard dancers trust the coach regarding nutrition and nutritional supplements, we concluded that sports dance coaches pay less attention to nutrition and physical fitness, and much more to technical and aesthetic preparation. The coach is most trusted by rock and roll representatives (18\%), who are probably also most concerned with dietary issues and nutritional supplements. This suggests that rock and roll coaches are also more likely to be nutritional educators and that they can advise their dancers on nutrition more than coaches in other dance disciplines. Interestingly, the majority of break-dancers obtain nutrition information on their own - through the internet and literature. Probably even the system of training process in breakdancing and in 
dance generally is not developed at all to the extent that coaches cooperate with physicians, maybe even nutritionists. Coaches should organize dancers to arrange nutritional regimes that would satisfy their energy requirements and be suitable even in in terms of maintaining a low body mass, which is important for certain dance disciplines.

The average knowledge of nutrition and nutritional supplements is the highest in acrobatic rock and roll dancers (5.3/10). Males need to be strong and explosive to be able to perform difficult acrobatics with the full weight of female dancers on their bodies, and despite their low body mass, female dancers must still be muscular, explosive, fast and powerful. That is why rock and roll representatives have been taught early about proper nutrition and are probably more interested in nutrition than other dancers. Knowledge about nutrition and nutritional supplements is estimated at 5.1 on average, which means that the results are comparable to the knowledge of other groups of athletes tested with the same questionnaire (Furjan-Mandić et al., 2013; Kondrič et al., 2013; Šajber et al., 2013; Šeme, 2016). For example, the average mark was $5.58 \pm 1.88$ for synchronous swimmers, $5.33 \pm 2.77$ for tennis players, and $3.50 \pm 0.80$ for Slovenian badminton players, with the best swimmers far reaching their knowledge (the mean score was 8.51 \pm 2.71 ).

Research shows (Diehl et al., 2011; Jeukendruo \& Cronin, 2011; Molinero \& Marquez, $2009)$ that the use of nutritional supplements in sports is already widespread (46-91\%) in the world, while the percentage of their regular consumption is slightly lower (Burckhardt, Wynn, Krieg, Bagutti, \& Faouzi 2011; Stensland \& Sobel, 1992). Probably due to poor nutrition information of not only dancers but also their trainers, many dancers are unaware of the benefits and effects of certain nutritional supplements.

Among the most commonly used nutritional supplements, dancers report vitamins, energy bars and isotonics. This may be due to their availability on the market, but at the same time it does not require a lot of knowledge to use them. The percentage of those who do not consume nutrition supplements is still high, but the values decline with success (Pruš et al., 2019). We are not surprised by the prevalence of vitamin supplements in the diet of dancers, as they have proven to be a major supplement in other dance disciplines (Burckhardt et al., 2011; Laws, 2005).

Dancers use vitamin supplements especially in the desire to maintain health, to boost and strengthen the immune system, to reduce and delay the phenomenon of fatigue and, consequently, to prevent injury (Brown \& Wyon, 2014). The latter was also confirmed by Boardley, Allen, Simmons, and Laws (2016), where the use of nutritional supplements reached its highest values $(91.9 \%)$.

Somewhat lower is the use of protein supplements, which are more commonly used by more successful dancers (Pruš et al., 2019), and in our study, the most by representatives of hip hop (regularly $10.8 \%$, occasionally $24.3 \%$ ) and rock and roll (regular $10 \%$, occasionally $25 \%$ ). We can conclude that dancers do not even have enough knowledge to properly include supplements in their nutritional regime. We suppose that many give up protein and carbohydrate supplements also because they are afraid of gaining weight. Challis et al. (2016) report that dancers have so-called "carbophobia" because they think that all carbohydrates and related sugars are poor and represent a source of "empty" calories.

Carbohydrates are a major limiting factor in overcoming effort and should account for as much as 55\% of a dancer's total diet (Sass, 2017). In dance training itself, there is no need for constant replenishment of energy reserves, but they may occur immediately before important competitions, when training is more frequent and the intensity is much higher. Training 
sessions prior to major competitions or performances are geared more towards gaining general endurance than the technical execution of the choreography itself. The so-called "dance" takes place at intervals where dancers do their best to dance only to individual parts of the competition choreography, or a whole that usually lasts from 1.5 to 3 minutes (Vučajnk \& Kljun, 2008), depending on the dance competition discipline. Knowing the importance and proper use of nutritional supplements can make it much easier for dancers during this period to both take part in the training system and to accelerate regeneration between training sessions.

Dancers acknowledge that the main reason for not using nutritional supplements is lack of knowledge or opinions that they may not benefit. The importance of knowledge as a determining factor for the use of nutritional supplements is also highlighted by Brown and Wyon (2014). We notice that there is still room for improvement in the field of dance. Dance is still frequently considered a hobby or recreational activity, and only a few (coaches and dancers) develop their professional careers. Quite a few dance coaches have no formal education, or coaching is their second profession for which they do not have enough time to complete additional training. The problem is that coaches and dancers spend more training (dance camps, preparations) on technical improvement and mastering different styles of dance than on physical fitness and related eating habits.

\section{CONCLUSION}

A number of established choreographers and coaches still continue to believe that the general fitness of the dancers is maintained through dance, while a number of studies confirm that dance training is not in itself a guarantee of sufficient intensity to allow dancers to maintain the aerobic and anaerobic endurance necessary to compete successfully. Proper body composition, which can be achieved through properly designed training and proper nutrition, is the starting point for developing movement skills that are crucial in top dance performance.

With our research we wanted to establish the dancers' knowledge and use of nutritional supplements in different dance disciplines. Despite their average assessment, we still want to raise the level of their lack of knowledge and awareness of nutrition issues. An analysis of the data showed that regular - every day - use of dietary supplements is present in $13.2 \%$ of female dancers and $24.4 \%$ of male dancers, which is far less than half of the surveyed dancers. They acknowledge that one of the main reasons for avoiding dietary supplements is their lack of education or lack of information.

Even though dancers do not feel the need to use nutritional supplements for most of the dance season, it would be essential for them, especially during major competitions, where dance performances are concentrated and the diet plan must be carefully planned. Dancers most often use nutritional supplements in the form of vitamin-mineral supplements, energy bars and isotonics during the competition period, but the inappropriate use of these may also impair the dancer's performance.

Certainly, further research is needed in the field of dance nutrition; most notably the comparison and connection of nutrition with the body composition and performance of dancers of different dance disciplines. However, we find that the nutrition and nutritional skills should be improved not only by dancers but also by their coaches, whom the dancers 
trust the most. Simple instructions such as "eat less" and "don't eat this and that" have become too insignificant in the world of advanced science in sports and nutrition to affect the performance of dancers. In developing the elite dancer - in terms of technical knowledge and the aesthetic component, a more consistent approach for healthy and adequate nutrition is needed. We think that it would be reasonable to implement intervention programs for young dancers and to place the field of nutrition and nutritional supplements in staff training courses for dance practitioners and coaches in Slovenia.

\section{REFERENCES}

Allen, N., \& Wyon, M. (2008). Dance medicine: Athlete or artist. Sport Ex Medicine Issue, 35, 6-9.

Biček, P. (2009). Telesna razvitost in prehranske navade športnih plesalk in plesalcev (Physical development and eating habits of sports dancers). Graduate paper, University of Ljubljana, Biotechnical Faculty). Retrieved June 20, 2019 from the World Wide Web: http://www.digitalna-knjiznica.bf.uni-lj.si/dn_bicek_polona.pdf

Boardley, I.A., Allen, N., Simmons, A., \& Laws, H. (2016). Nutritional, medicinal, and performance enhancing supplementation in dance. Performance Enhancement \& Health, 4(1-2), 3-11.

Bria, S., Bianco, M., Galvani, C., Palmieri, V., Zeppilli, P., \& Faina, M. (2011). Physiological characteristics of elite sport-dancers. The Journal of Sports Medicine and Physical Fitness, 51(2), 194-203.

Bronner, S., Ojofeitimi, S., \& Woo, H. (2015). Extreme kinematics in selected hip hop dance sequences. Medical Problems of Performing Artists, 30(3), 126-134.

Brown, D., \& Wyon, M. (2014). An international study on dietary supplementation use in dancers. Medical Problems of Performing Artists, 29(4), 229-234.

Burns, R.D., Schiller, M.R., Merrick, M.A., \& Wolf, K.N. (2004). Intercollegiate student athlete use of nutritional supplements and the role of athletic trainers and dietitians in nutrition counselling. Journal of American Dietetic Association, 104(2), 246-259.

Burckhardt, P., Wynn, E., Krieg, M. A., Bagutti, C., \& Faouzi, M. (2011). The effects of nutrition, puberty and dancing on bone density in adolescent ballet dancers. Journal of Dance Medicine \& Science, 15(2), 51-60.

Civil, R., Lamb, A., Loosmore, D., Ross, L., Livingstone, K., Strachan, F., et al. (2018). Assessment of dietary intake, energy status, and factors associated with red-s in vocational female ballet students. Frontiers in Nutrition, 5, 136.

Challis, J., Stevens, A., \& Wilson, M. (2016). Nutrition Resource Paper 2016. International Association for Dance Medicine \& Science. Retrieved June 15, 2019 from: https://c.ymcdn.com/sites/www.iadms.org/resource/ resmgr/resource_papers/dance-nutrition-2016.pdf

Desbrow, B., Burd, N.A., Tarnopolsky, M., Moore, D.R., \& Elliott-Sale, K.J. (2019). Nutrition for special populations: Young, female, and masters athletes. International Journal of Sport Nutrition and Exercise Metabolism, 29(2), 220-227.

Diehl, K., Thiel, A., Zipfel, S., Mayer, J., Schnell, A., \& Schneider, S. (2012). Elite adolescent athletes' use of dietary supplements: Characteristics, opinions, and sources of supply and information. International Journal of Sport Nutrition and Exercise Metabolism, 22(3), 165-174.

Dotti, A., Fioravanti, M., Balotta, M., Tozzi, F., Cannella, C., \& Lazzari, R. (2002). Eating behavior of ballet dancers. Eating and Weight disorders, 7(1), 60-67.

Elpidoforou, M. (2016). Types of dance: Steps and position. In: V.A. Angoules (Ed.), Overuse injuries in dancers, (pp. 1-9). OMICS International eBooks.

Furjan-Mandić, G., Perić, M., Krželj, L., Stanković, S., \& Zenić, N. (2013). Sports nutrition and doping factors in synchronized swimming: parallel analysis among athletes and coaches. Journal of Sports Science and Medicine 12, 753-760.

Hidayah, G.N., \& Syahrul Bariah, A.H. (2011). Eating attitude, body image, body composition and dieting behaviour among dancers. Asian Journal of Clinical Nutrition, 3(3), 92-102.

Hunt, K.J. (2011). Eat to live, live to dance: Preventing eating disorders in dancers. Journal of the Utah Academy of Sciences, Arts \& Letters, 88, 348-367.

Jeukendruo, A., \& Cronin, L. (2011). Nutrition and elite young athletes. Medicine and Sport Science, 56, 47-58.

Kondrič, M., Sekulić, D., Uljević, O., Gabrilo G., \& Žvan, M. (2013). Sport nutrition and doping in tennis: an analysis of athletes' attitudes and knowledge. Journal of Sports Science and Medicine, 12, 290-297.

Kostić, R., Zagorc, M., \& Uzunović, S. (2004). Prediction of success in sports dancing based on morphological characteristics and functional capabilities. Acta Universitatis Palackianae Olomucensis Gymnica, 34(1), 59-64. 
Koutedakis, Y., \& Jamurtas, A. (2004). The dancer as a performing athlete. Sports Medicine, 34(10), 651-661. Koutedakis, Y. (1996). Nutrition to fuel dance: A brief review. Dance Research: The Journal of the Society for Dance Research, 14(2), 76-93.

Laws, H. (2005). Fit to dance 2: Report of the second national inquiry into dancers' health and injury in the UK. London, Dance UK.

Malkogeorgos, A., Zaggelidou, E., Zaggelidis, G., \& Christos, G. (2013). Physiological elements required by dancers. Sport Science Review, 22(5-6), 343-368.

Molinero, O., \& Marquez, S. (2009). Use of nutritional supplements in sports: Risks, knowledge, and behavioural-related factors. Nutrition Hospitalaria, 24(2), 128-134

Pacy, P., Khalouha, M., \& Koutedakis, Y. (1996). Body composition, weight control and nutrition in dancers. Dance Research: The Journal of the Society for Dance Research, 14(2), 93-105.

Perić, M., Zenić, N., Sekulić, D., Kondrič, M., \& Zaletel, P. (2016). Disordered eating, amenorrhea, and substance use and misuse among professional ballet dancers: Preliminary analysis. Medycyna Pracy, 67(1), 21-27.

Pruš, D. (2015). Telesne značilnosti in gibalne sposobnosti plesalk in plesalcev hip-hopa (Physical characteristics and movement skills of hip-hop dancers and dancers). Thesis. Faculty of Sport, Ljubljana. In Slovenian

Pruš, D. (2018). Poznavanje in uporaba prehranskih dodatkov pri plesalkah in plesalcih hip-hop plesa (Knowledge and use of nutritional supplements for dancers and hip-hop dancers). Faculty of Sport, Ljubljana. Master thesis. Faculty of Sport, Ljubljana. In Slovenian

Pruš, D., Kondrič, M., Hadžić, V., \& Zaletel, P. (2019). Knowledge and use of nutritional supplements among hip-hop dancers. Sport Mont Journal, 17(3), 33-39.

Sass, C. (2017). Can carb cycling help you lose weight? Health. Retrieved June 202019 from the World Wide Web: http://www.health.com/weight-loss/carb-cycling

Sekulić, D., Perić, M., \& Rodek, J. (2010). Substance use and misuse among professional ballet dancers. Substance Use \& Misuse, 5(9), 1420-1430.

Sekulić, D., Bjelanović, L., Pehar, M., Pelivan, K., \& Zenic, N. (2014a). Substance use and misuse and potential doping behaviour in rugby union players. Research in Sports Medicine, 22(3) 226-239.

Sekulić, D., Milanović, I., Bok, D., Jukić, I., \& Matika, D. (2014b). Substance use and misuse in the Croatian Army Special Forces: prevalence and influencing factors. International Journal of Occupational Medicine and Envirobmental Health, 27(1), 123-131.

Sousa, M., Carvalho, P., Moreira, P., \& Teixeira, V. H. (2013). Nutrition and nutritional issues for dancers. Medical Problems of Performing Artists, 28(3), 119-123.

Stensland, S.H., \& Sobal, J. (1992). Dietary practices of ballet, jazz, and modern dancers. Journal of the American Dietetic Association, 92(3), 319-324.

Šajber, D., Rodek, J., Escalante, Y., Olujić, D., \& Sekulić, D. (2013). Sport nutrition and doping factors in swimming: Parallel analysis among athletes and coaches. Collegium Antropologicum, 37(2), 179-186.

Šeme, T. (2016). Poznavanje in uporaba dovoljenih in prepovedanih substanc v badmintonu (Knowledge and use of permitted and prohibited substances in badminton). Master's thesis. University of Ljubljana, Faculty of Sport. Retrieved June 20, 2019 from the World Wide Web: https://www.fsp.uni-lj.si/cobiss/mag/ Magisterij22066470SemeTadej.pdf

Uzunović, S., \& Kostić, R. M. (2005). A study of success in Latin American sport dancing. Facta Universitatis Series Physical Education and Sport, 3(1), 23-35.

Vučajnk, V., \& Kljun, Z. (2008). Tekmovalni pravilnik moderni tekmovalni plesi (Competition rules of modern competitive dances). Dance Union of Slovenia. Retrieved June 212019 from: https://d27h45gomdtbj. cloudfront.net/sofa/uploads/comfy/cms/files/51.original.pdf

Zaletel, P., Sekulić, D., Zenić, N., Esco, M.R., Šajber, D., \& Kondrič, M. (2017). The association between bodybuilt and injury occurrence in pre-professional ballet dancers - Separated analysis for the injured bodylocations. International Journal of Occupational Medicine and Environmental Health, 30(1), 151-159.

Zaletel, P., Veršić, Š., Perić, M., Zenić, N., Sekulić, D., \& Kondrič, M. (2015). Toward (more) effective antidoping policy in sports: what should we target in antidoping efforts? Medicina Dello Sport, 68, 447-460.

Zenić, N., Perić, M., Zubčević, N. G., Ostojić, Z., \& Ostojić, L. (2010). Comparative analysis of substance use in ballet, dance sport, and synchronized swimming: results of a longitudinal study. Medical Problems of Performing Artists, 25(2), 75-81.

Wyon, M., Hutchings, K., Wells, A., \& Nevill, A.M. (2014). Body mass index, nutritional knowledge, and eating behaviours in elite student and professional ballet dancers. Clinical Journal of Sports Medicine: official journal of the Canadian Academy of Sports Medicine, 24(5), 390-396. 


\section{ZNANJE I UPOTREBA DIJETETSKIH SUPLEMENATA U RAZLIČITIM DISCIPLINIMA PLESA}

$U$ estetskim sportovima izgled tela $i$ vitka figura igraju važnu ulogu, pa je unos energije često nedovoljan. Ograničavanjem količine konzumirane hrane dolazi do specifičnih deficita koji utiču na zdravlje i performanse plesača. Upotreba dijetetskih suplemenata često nadoknađuje nedostatak unosa hranljivih sastojaka i omogućava bržu regeneraciju. Ova studija imala je za cilj da analizira znanje o ishrani i dodacima ishrani kod muških $i$ ženskih plesača četiri različite plesne discipline: hip hop, latinoamerički i standardni plesovi, akrobatski rock and roll i breakdance. Uzorak se sastojao od 98 plesača (prosečne starosti 18.8 godina), koji su upoređeni po polu i njihovom uključenošću u plesnu disciplinu. Njihova prosečna dužina plesne karijere je 9,7 godina. Utvrđeno je da plesači imaju prosečno znanje o ishrani $i$ dodacima ishrani (5.1/10). Plesači najviše poverenja imaju u lekare $i$ trenere kada je u pitanju znanje o ishrani. Plesači prikupljaju informacije o dijetetskim suplementima uglavnom od trenera ili od nastavnika u školi, a neki plesači to čine i samostalno, putem interneta $i$ literature. Manje od polovine plesačica ne koristi dodatke prehrani. Većina njih konzumira energetske $i$ vitaminsko-mineralne dodatke. Muškarci redovno konzumiraju vitaminsko-mineralne suplemente (26.7\%), povremeno energetski efikasnije dodatke (42\%) i izotonike (26.6\%). Predstavnici različitih plesnih disciplina ne razlikuju se značajno u znanju i upotrebi dijetetskih suplemenata. Rukometaši imaju najvišu prosečnu oсепu u nutricionističkom znanju (5.3/10).

Ključne reči: ishrana, suplementi, ples, znanje 